\title{
Enzymatic production of lactulose and epilactose in milk
}

\author{
Eva Rentschler, Katharina Schuh, Manuel Krewinkel, Claudia Baur, Wolfgang Claaßen, Susanne Meyer, \\ Beatrice Kuschel, Timo Stressler, ${ }^{1}$ and Lutz Fischer \\ University of Hohenheim, Institute of Food Science and Biotechnology, Department of Biotechnology and Enzyme Science, Garbenstr. 25, \\ 70599 Stuttgart, Germany
}

\begin{abstract}
The enzymatic production of lactulose was described recently through conversion of lactose by a thermophilic cellobiose 2-epimerase from Caldicellulosiruptor saccharolyticus $(\mathrm{Cs} \mathrm{CE})$. In the current study, we examined the application of $C s \mathrm{CE}$ for lactulose and epilactose production in milk ( $1.5 \%$ fat). The bioconversions were carried out in stirred reaction vessels at 2 different temperatures $\left(50\right.$ and $\left.8^{\circ} \mathrm{C}\right)$ at a scale of $25 \mathrm{~mL}$ volume. At $50^{\circ} \mathrm{C}, 2$ highly different $C s \mathrm{CE}$ amounts were investigated for the time course of formation of lactulose and epilactose. The conversion of milk lactose (initial lactose content of $48.5 \pm 2.1 \mathrm{~g} / \mathrm{L}$ ) resulted in a final yield of $57.7 \%(28.0 \mathrm{~g} / \mathrm{L})$ lactulose and $15.5 \%(7.49$ $\mathrm{g} / \mathrm{L})$ epilactose in the case of the approximately 9.5fold higher $C s \mathrm{CE}$ amount $\left(39.5 \mu\right.$ kat $\left._{\text {epilactose, }} 50^{\circ} \mathrm{C}\right)$ after $24 \mathrm{~h}$. Another enzymatic lactose conversion was carried out at low $8^{\circ} \mathrm{C}$, an industrially relevant temperature for milk processing. Although the $C s \mathrm{CE}$ originated from a thermophilic microorganism, it was still applicable at $8^{\circ} \mathrm{C}$. This enzymatic lactose conversion resulted in $56.7 \%(27.5 \mathrm{~g} / \mathrm{L})$ lactulose and $13.6 \%(6.57 \mathrm{~g} / \mathrm{L})$ epilactose from initial milk lactose after $72 \mathrm{~h}$. The time courses of lactose conversion by $C s \mathrm{CE}$ suggested that first epilactose formed and afterward lactulose via epilactose. To the best of our knowledge, this is the first time that an enzyme has produced lactulose directly in milk in situ at industrially relevant temperatures.
\end{abstract}

Key words: cellobiose 2-epimerase, lactulose, epilactose, milk, prebiotic

\section{INTRODUCTION}

The disaccharide lactulose (4-O- $\beta$-D-galactopyranosylD-fructofuranose) is one of the most valuable lactose derivatives and possesses prebiotic properties (Petuely,

Received June 2, 2015

Accepted June 21, 2015.

${ }^{1}$ Corresponding author: t.stressler@uni-hohenheim.de
1957; Olano and Corzo, 2009). The application of lactulose as a functional food ingredient has been researched since 1957 (Petuely, 1957; Panesar and Kumari, 2011; Aït-Aissa and Aïder, 2014). An intake from 2 to $10 \mathrm{~g}$ of lactulose/d has been assigned to present prebiotic action (Terada et al., 1992; Mizota et al., 2002; Tuohy et al., 2002; Seki et al., 2007). This positive influence on the intestinal function has the potential to provide health benefits by alteration of colon microbiota as well as enhancing mineral adsorption as determined in several clinical trials (Oku and Okazaki, 1998; Seki et al., 2007; Sharma et al., 2008; Schuster-Wolff-Bühring et al., 2010). In Japan, the nutritional benefits of lactulose were acknowledged by the Japanese Ministry of Health and Welfare who claimed it as a "food of specific health use." Seki and Saito (2012) mentioned some functional food products containing lactulose (e.g., infant formula, soft drinks, and yogurt).

Lactose (4-O- $\beta$-D-galactopyranosyl-D-glucose) is isomerized to lactulose in milk during milk processing by a chemical reaction via the Lobry de Bruyn-Alberda van Ekenstein rearrangement, which is catalyzed by heat treatment and alkaline conditions (SchusterWolff-Bühring et al., 2010). According to this reaction, 0.1 to $0.9 \mathrm{~g} / \mathrm{L}$ of lactulose can be found in UHT milk (Cattaneo et al., 2008; Manzi and Pizzoferrato, 2013). Industrial lactulose production has been carried out by chemical isomerization up to now. This process includes the use of chemical catalysts and various purification steps (Aïder and de Halleux, 2007; Schuster-WolffBühring et al., 2010). Research has focused on finding alternative enzymatic processes to overcome these drawbacks during recent years. One approach is the use of $\beta$-galactosidases via the transgalactosylation reaction with lactose and fructose as substrates (Kim et al., 2006; Mayer et al., 2010; Guerrero et al., 2011). The disadvantage of this process is the need of the sweet co-substrate fructose (galactose acceptor), which is a cost and taste factor, respectively.

Regarding dairy products as yogurt or formula milk, the addition of commercially available lactulose can be redundant by generating lactulose in situ from initial 
milk lactose. This new approach of integrating the lactulose formation in the processing of a dairy product was recently described by Förster-Fromme et al. (2011). The research group produced a lactulose-containing milk serum drink by application of a $\beta$-galactosidase from Aspergillus oryzae to whey powder $(6.9 \mathrm{~g} / \mathrm{L}$ of lactose) along with $90 \mathrm{~g} / \mathrm{L}$ of fructose.

Ito et al. (2008) reported that a cellobiose 2-epimerase (CE; EC 5.1.3.11) from Ruminococcus albus catalyzed the epimerization reaction of lactose into epilactose (4- $O$ - $\beta$-D-galactosyl-D-mannose), another valuable lactose derivate (Watanabe et al., 2008). Further research regarding this enzyme class led to the identification of 2 thermophilic CE from Caldicellulosiruptor saccharolyticus $(\boldsymbol{C s} \mathbf{C E})$ and Dictyoglomus turgidum. Both enzymes catalyzed not only the epimerization reaction, but also a further isomerization reaction (Park et al., 2011; Kim et al., 2012). This novel isomerization reaction led to the enzymatic formation of lactulose from lactose. Thus, the application of $C s \mathrm{CE}$ to milk may lead to a novel way of generating lactulose-enriched dairy products with prebiotic properties in situ. The enzymatic synthesis could be integrated in the processing of dairy products, which offers the opportunity to turn a byproduct like whey or whey permeate into a valuable prebiotic product.

The enzymatic lactulose production from lactose by $\mathrm{CE}$ has only been investigated in synthetic buffer systems at high temperatures up to now (Kim and Oh, 2012; Kim et al., 2012). In the current study, the enzymatic lactulose production in milk was investigated for the first time. The application of the $\mathrm{CE}$ from C. saccharolyticus was performed under varied reaction conditions, such as altered initial enzyme activity and temperature. Experiments were carried out at $8^{\circ} \mathrm{C}$, a typical temperature used in the milk industry, to illustrate the possible industrial applications of this enzymatic process.

\section{MATERIALS AND METHODS}

\section{Chemicals, Enzymes, and Milk}

All chemicals were of analytical grade or higher and supplied by Alfa Aesar (Heysham, UK), Merck (Darmstadt, Germany), Carl Roth (Karlsruhe, Germany), or Sigma-Aldrich (St. Louis, MO). The T4 DNA ligase was purchased from Fisher Scientific (Schwerte, Germany) and restriction enzymes and DNA polymerase were purchased from New England Biolabs (Ipswich, MA). The UHT milk containing $1.5 \%$ fat (fettarme, haltbare Weidemilch 1.5\%, Schwarzwaldmilch GmbH, Freiburg, Germany) was obtained from a local supermarket.

\section{Microorganisms, Plasmids, and Gene Cloning}

The strains Escherichia coli XL-1 Blue (New England Biolabs, Ipswich, MA) and E. coli BL21 (DE3) were used for cloning and expression. The genomic DNA sequence of CE from C. saccharolyticus DSM 8903 was obtained from the European Molecular Biology Laboratory, European Bioinformatics Institute (ENA Association No. ABP65941.1). The $C s \mathrm{CE}$ gene was purchased as a synthetic gene with added NdeI and BamHI restriction sites in a pMA vector from Life Technologies (Carlsbad, CA). Prior to the synthesis, optimized codon usage for expression in E. coli was achieved using Gene Designer (DNA2.0 Inc., Menlo Park, CA). In general, standard molecular biology methods according to Sambrook and Russell (2001) were used. After subcloning in pET-16b by NdeI and BamHI, a PCR was performed using the primer pair csce_fw (5' GACCACAACGGTTTCCCTCTAG $3^{\prime}$ ) and csce_rev (5' GATCTCGAGATCCACGCG-TTTGATAATTTCC $3^{\prime}$ ). Subcloning in pET-20b $(+)$ by $N d e \mathrm{I}$ and $X h o \mathrm{I}$ was carried out to introduce a C-terminal hexahistidine tag $\left(\mathbf{H i s}_{6}\right.$-Tag), followed by transformation in E. coli XL-1 Blue. The resulting construct pET-20bCSCE was transformed in $E$. coli BL21 (DE3) for the expression of the CsCE.

\section{Production, Purification, and Molecular Mass Determination of CsCE}

Escherichia coli BL21 (DE3) pET-20bCSCE was cultivated in $15 \mathrm{~L}$ of 2-yeast-tryptone medium containing $16 \mathrm{~g} / \mathrm{L}$ of tryptone, $10 \mathrm{~g} / \mathrm{L}$ of yeast extract, 20 $\mathrm{g} / \mathrm{L}$ of glucose, and $100 \mu \mathrm{g} / \mathrm{mL}$ of ampicillin in a $23-\mathrm{L}$ stirred tank reactor (Biostat E. B. Braun, Melsungen, Germany) for $11 \mathrm{~h}$. The expression of the $C s \mathrm{CE}$ was induced at an optical density $(600 \mathrm{~nm})$ of 6.5 with $0.5 \mathrm{~m} M$ isopropyl- $\beta$-D-thiogalactopyranoside after 2.25 $\mathrm{h}$ of cultivation at $37^{\circ} \mathrm{C}$. The cultivation was continued for $8.75 \mathrm{~h}$ at $20^{\circ} \mathrm{C}$. The $\mathrm{pH}$ was regulated to 7.0 by adding $2 \mathrm{M} \mathrm{NaOH}$ and $0.6 M \mathrm{H}_{3} \mathrm{PO}_{4}$.

The recombinant $E$. coli cells were harvested by centrifugation $\left(8,000 \mathrm{~g}, 15 \mathrm{~min}, 4^{\circ} \mathrm{C}\right)$ and washed twice with $0.9 \%$ (wt/vol) $\mathrm{NaCl}$ solution. Subsequently, the cells were resuspended in $50 \mathrm{~m} M$ sodium phosphate buffer, pH 7.5, containing $300 \mathrm{mM} \mathrm{NaCl}$, to obtain a $30 \%$ (wt/vol) cell suspension. The cell disruption was carried out by a 10 cycle sonication program on ice. Each cycle consisted of 1 min of sonication (95\% amplitude, 0.5 cycles; UP200S/S3, Hielscher Ultrasonics, Teltow, Germany) and a break of $1 \mathrm{~min}$. Cell debris was removed by centrifugation $\left(8,000 \times g, 15 \mathrm{~min}, 4^{\circ} \mathrm{C}\right)$. Afterward, the supernatant was heated for $15 \mathrm{~min}$ at $60^{\circ} \mathrm{C}$ and, subsequently, centrifuged $\left(8,000 \times g, 15 \mathrm{~min}, 4^{\circ} \mathrm{C}\right)$ 
to remove denatured E. coli proteins. The supernatant containing $C s \mathrm{CE}$ was filtered $(0.45 \mu \mathrm{m})$ and further purified using an ÄKTA FPLC system (GE Healthcare, Little Chalfont, UK) equipped with a $\mathrm{Ni}^{2+}$-charged iminodiacetic acid column (column volume $=12 \mathrm{~mL}$; Profinity IMAC, BioRad, Hercules, CA). Before sample application $(48 \mathrm{~mL})$, the column was equilibrated with binding buffer $(50 \mathrm{mM}$ sodium phosphate buffer, $\mathrm{pH} 7.5,300 \mathrm{mM} \mathrm{NaCl}$ ). Unbound protein was eluted for 5 column volumes at a flow rate of $1 \mathrm{~mL} / \mathrm{min}$ using binding buffer. Bound $C s \mathrm{CE}$ was eluted using a linear gradient over 2 column volumes from 0 to $50 \%$ elution buffer (binding buffer $+500 \mathrm{~m} M$ imidazole) at a flow rate of $1 \mathrm{~mL} / \mathrm{min}$. Afterward, the column was cleaned by a step to $100 \%$ elution buffer; this setup was held for 2 column volumes. During chromatography, eluted protein was detected at $280 \mathrm{~nm}$ and fractions $(5 \mathrm{~mL})$ were collected. The active fractions were desalted using PD-10 columns (GE Healthcare, Little Chalfont, UK) to $10 \mathrm{~m} M$ 1,4-piperazinediethanesulfonic acid (PIPES) buffer, $\mathrm{pH} 7.5$, containing $100 \mathrm{mM} \mathrm{NaCl}$. The addition of $100 \mathrm{~m} \mathrm{M} \mathrm{NaCl}$ was performed to avoid protein precipitation. The resulting enzyme solution was freeze-dried (Alpha 1-2, Martin Christ Gefriertrocknungsanlagen, Osterode am Harz, Germany) to gain a lyophilized $C s \mathrm{CE}$ preparation for the later application in milk. The freeze-dried enzyme preparation was stored at $-20^{\circ} \mathrm{C}$.

The protein concentration of $C s \mathrm{CE}$ was determined by the method of Bradford (1976) with bovine serum albumin as a standard. To examine the quality of the $C s \mathrm{CE}$ expression and purification, $12.5 \%$ SDS-PAGE were used (Laemmli, 1970). The protein bands were stained with Coomassie Brilliant Blue R-250, according to the method of Fairbanks et al. (1971). The protein molecular mass standard (2-212 kDa) used was obtained from New England Biolabs (Ipswich, MA).

\section{Determination of CsCE Activity}

The activity of $C s \mathrm{CE}$ was measured using lactose as a substrate. The standard assay for the determination of enzyme activity was performed in $300 \mu \mathrm{L}$ reaction volume, adapted from Kim and Oh (2012). In contrast to $\mathrm{Kim}$ and $\mathrm{Oh}$ (2012), the $\mathrm{CsCE}$ activity was determined measuring the increase of epilactose, the product of the epimerization reaction. The reason for this is that lactulose was not generated in the time frame of the assay measurements (generally between 4 and 10 min). The reaction mixture of $10 \mathrm{~m} M$ PIPES buffer, $100 \mathrm{~m} M \mathrm{NaCl}$, pH 7.5, containing $100 \mathrm{~g} / \mathrm{L}$ lactose $(150 \mu \mathrm{L})$ and enzyme in $10 \mathrm{~m} M$ PIPES buffer, $100 \mathrm{mM}$ $\mathrm{NaCl}, \mathrm{pH} 7.5(150 \mu \mathrm{L})$, was incubated at $80^{\circ} \mathrm{C}$ for an appropriate time. The reaction was stopped by adding
$2 \mathrm{MHClO}_{4}(150 \mu \mathrm{L})$. The determination of the concentrations of lactose and epilactose formed was performed by HPLC analysis (see below). One katal of $C s \mathrm{CE}$ activity was defined as the amount of enzyme required to produce $1 \mathrm{~mol}$ of epilactose from lactose per second at the respective temperature and $\mathrm{pH} 7.5$.

Samples $(1 \mathrm{~mL})$ were taken for stability measurement during enzymatic lactose conversion. These samples were applied to a PD-10 column (GE Healthcare) before enzyme activity determination to remove indigenous milk sugars and formed saccharides of the enzymatic lactose conversion. Elution of protein was achieved by using $10 \mathrm{~m} M$ PIPES buffer and $100 \mathrm{mM} \mathrm{NaCl}$ at pH 7.5. The samples $(150 \mu \mathrm{L})$ were tested for $C s \mathrm{CE}$ activity using the assay described above at the respective temperature $\left(50^{\circ} \mathrm{C}\right.$ or $\left.8^{\circ} \mathrm{C}\right)$.

\section{HPLC Methods for Sugar Quantification}

The stopped enzymatic reaction samples (see above) were incubated on ice for $10 \mathrm{~min}$, following a centrifugation step $\left(13,000 \times g, 3 \mathrm{~min}, 4^{\circ} \mathrm{C}\right)$. Neutralization of the particular supernatant $(300 \mu \mathrm{L})$ was realized with $2 M \mathrm{KOH}(100 \mu \mathrm{L})$. Afterward, the internal standard (200 $\mathrm{LL} ; 20 \mathrm{~m} M$ xylose, $20 \mathrm{~m} M$ sorbitol) was added. Subsequently, adapted from Erich et al. (2012), a 200$\mu \mathrm{L}$ aliquot of the sample was subjected to a pre-column derivatization with $200 \mu \mathrm{L}$ of $0.9 M p$-aminobenzoic acid solved in dimethyl sulfoxide/acetic acid solution (70/30; vol/vol) and $10 \mathrm{mg}$ sodium cyanoborohydride for $30 \mathrm{~min}$ at $60^{\circ} \mathrm{C}$. Afterward, the samples were cooled on ice.

The HPLC equipment used to determine the concentrations of lactose and epilactose was composed of a Thermo Finnigan System SCM1000 (Thermo Scientific, Waltham, MA) equipped with a Finnigan Surveyor UV/VIS detector with a detection wavelength of $303 \mathrm{~nm}$ (Thermo Finnigan) and a Hypersil BDS C18 column $(250 \times 4.4 \mathrm{~mm}, 3 \mu \mathrm{m}$, Thermo Scientific $)$. The separation of sugars was adapted from Erich et al. (2012). The analysis temperature was $25^{\circ} \mathrm{C}$ and 20 $\mathrm{m} M$ tetrabutylammonium hydrogen sulfate (ion-pair reagent) in $50 \mathrm{~m} M$ sodium phosphate buffer $\mathrm{pH} 2.0$ was used as an eluent (flow rate: $0.5 \mathrm{~mL} / \mathrm{min}$ ). The samples were diluted with HPLC eluent before injection into the HPLC system $(10 \mu \mathrm{L})$.

A second HPLC system (Agilent Series 1100) was used for the detection of lactulose, the reaction product of the isomerization of lactose by $C s \mathrm{CE}$ formed during enzymatic lactose conversion in milk. The HPLC was equipped with an Acclaim Trinity P2 column $(3.0 \times$ $100 \mathrm{~mm}, 3 \mu \mathrm{m}$, Thermo Scientific) and an evaporative light scattering detector (Sedex 85LT, Sedere, Alfort- 
ville Cedex, France) at $50^{\circ} \mathrm{C}$ and 3.5 bar. The column was eluted with $80 \%$ acetonitrile and $20 \% 100 \mathrm{mM}$ ammonium formiate buffer, $\mathrm{pH} 3.65$, at a flow rate of $0.5 \mathrm{~mL} / \mathrm{min}$ at $60^{\circ} \mathrm{C}$. After dilution with the respective HPLC eluent, $5 \mu \mathrm{L}$ of prepared sample (see above) was injected into the HPLC system.

\section{Enzymatic Lactose Conversion in Milk and UHT Treatment}

Enzymatic lactose conversions were carried out in UHT milk containing $1.5 \%$ fat and an initial lactose content of $48.5 \pm 2.1 \mathrm{~g} / \mathrm{L}$ (fettarme, haltbare Weidemilch 1.5\%, Schwarzwaldmilch GmbH, Freiburg, Germany) in a 100-mL jacket stirred reaction vessel (working volume: $25 \mathrm{~mL}$ ) at $50 \pm 1^{\circ} \mathrm{C}$ or $8 \pm 1^{\circ} \mathrm{C}$ for $24 \mathrm{~h}$ or $72 \mathrm{~h}$, respectively. All experiments were carried out in duplicate in 2 separate reaction vessels. A third vessel without the addition of the enzyme was used for a negative control. The purified $C s \mathrm{CE}$ solution was freeze-dried directly in the vessels and resulted in an initial enzyme activity of $166 \pm 9$ nkat $_{\text {epilactose, } 50^{\circ} \mathrm{C} /}$

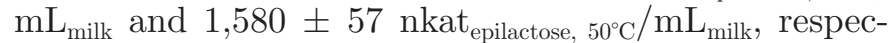
tively, after resolubilization in milk. The initial $C s \mathrm{CE}$

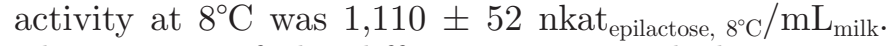
The content of the different sugars and the enzyme activity was determined during the enzymatic lactose conversion. Samples were taken for sugar quantification over $24 \mathrm{~h}$ in the case of the $50^{\circ} \mathrm{C}$ enzymatic lactose conversions. For the enzymatic lactose conversions at $8^{\circ} \mathrm{C}$, additional samples were taken after 36,48 , and $72 \mathrm{~h}$. The residual enzyme activity was investigated after 0,6 , and $24 \mathrm{~h}$ at $50^{\circ} \mathrm{C}$. Additionally, the residual activity after $72 \mathrm{~h}$ was analyzed for the $8^{\circ} \mathrm{C}$ enzymatic lactose conversion. To investigate a possible inactivation step of $C s \mathrm{CE}$ during milk processing, an exemplary UHT treatment in a batch heating system, described by Dogan et al. (2009), was performed. A volume of $1.5 \mathrm{~mL}$ of milk containing $108 \pm 4.96 \mathrm{nkat}_{\text {epilactose, } 50^{\circ} \mathrm{C} /}$ $\mathrm{mL}_{\text {milk }} C_{\mathrm{sCE}}$, corresponding to the residual activity after $24 \mathrm{~h}$ of enzymatic lactose conversion in milk, was held above $138^{\circ} \mathrm{C}$ for $12 \mathrm{~s}$ and cooled down to $8^{\circ} \mathrm{C}$. Milk samples $(1 \mathrm{~mL})$ were processed as formerly mentioned and $C s \mathrm{CE}$ activity was determined with lactose as a substrate as described above.

\section{Statistics and Replication of Experiments}

Determinations of enzyme activity and analytic measurements were performed at least in duplicate. Data are shown as means \pm standard deviations. Calculations, statistical analysis, and the visualization of enzymatic lactose conversions were executed with Excel (Microsoft Corporation, Redmond, WA).

\section{RESULTS}

\section{Production and Purification of CsCE}

The strain E. coli BL21 (DE3) and the plasmid pET$20 \mathrm{~b} C S C E(+)$ were used as a host/vector system for the recombinant production of CE from C. saccharolyticus. The AA sequence of the thermophilic $C s \mathrm{CE}$ resulted in the same sequence as described previously by Park et al. (2011), including an additional C-terminal His $_{6}$-tag for a straightforward purification. The $C s \mathrm{CE}$ production was performed in a stirred tank bioreactor $(15 \mathrm{~L}$ working volume) over $11 \mathrm{~h}$. The cells were harvested by centrifugation, resulting in approximately $150 \mathrm{~g}$ of dry biomass $(\sim 417 \mathrm{~g}$ of wet biomass) and an enzyme

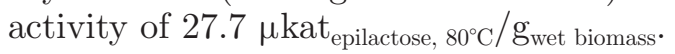

Prior to the purification, the cells were suspended in sodium phosphate buffer $(50 \mathrm{mM})$, $\mathrm{pH} 7.5$, containing $\mathrm{NaCl}(300 \mathrm{mM})$ and disrupted by sonication. A clear, cell-free crude extract was obtained after subsequent centrifugation. This crude extract was heated at $60^{\circ} \mathrm{C}$ for $15 \mathrm{~min}$ as the $\mathrm{CsCE}$ is a heat-stable enzyme and remained soluble and active in solution. However, several E. coli proteins, denatured during this heating step, precipitated and were separated by centrifugation. The clear supernatant obtained was chromatographically purified using a $\mathrm{Ni}^{2+}$-charged His-trap affinity column. The purification is summarized in Table 1 . The $C s \mathrm{CE}$ was purified 9.5-fold with an overall activity yield of $52 \%$ and a specific activity of $3.32 \mu$ kat $_{\text {epilactose, }} 80^{\circ} \mathrm{C} /$ $\mathrm{mg}_{\text {protein }}$ with lactose as the substrate. The purified $C s \mathrm{CE}$ was applied for all following investigations. The overexpression of $C s \mathrm{CE}$ and its purification was examined by SDS-PAGE (Figure 1). The $C s \mathrm{CE}$ was identified as a strong $41.2-\mathrm{kDa}$ protein band. This is in accordance with the theoretical calculated mass of $C s \mathrm{CE}$ with an additional $\mathrm{His}_{6}$-tag $(47.3 \mathrm{kDa})$.

\section{In Situ Production of Lactulose and Epilactose Using CsCE}

The production of lactulose and epilactose by purified $C s \mathrm{CE}$ was investigated in commercial UHT milk $\left(1.5 \%\right.$ fat) at 8 and $50^{\circ} \mathrm{C}$. Both these temperatures should be relevant for enzymatic milk processing in industry. Microbial growth is not very likely at 8 and $50^{\circ} \mathrm{C}$ and undesirable sensorial modifications of the taste should be more or less negligible (Gaucher et al., 2008; Tossavainen, 2008; Richards et al., 2014). The latter is especially true for milk processing at $8^{\circ} \mathrm{C}$. The specific $C s \mathrm{CE}$ activity of the purified sample used in all enzymatic lactose conversion studies was $3.32 \pm$ $0.07 \mu$ kat $_{\text {epilactose, } 80^{\circ} \mathrm{C}} / \mathrm{mg}_{\text {protein }}$ at $80^{\circ} \mathrm{C}(100 \%), 2.02 \pm$ $0.05 \mu \mathrm{kat}_{\text {epilactose, }} 50^{\circ} \mathrm{C} / \mathrm{mg}_{\text {protein }}$ at $50^{\circ} \mathrm{C}$ (approximately 
Table 1. Purification of recombinant cellobiose 2-epimerase from Caldicellulosiruptor saccharolyticus (CsCE)

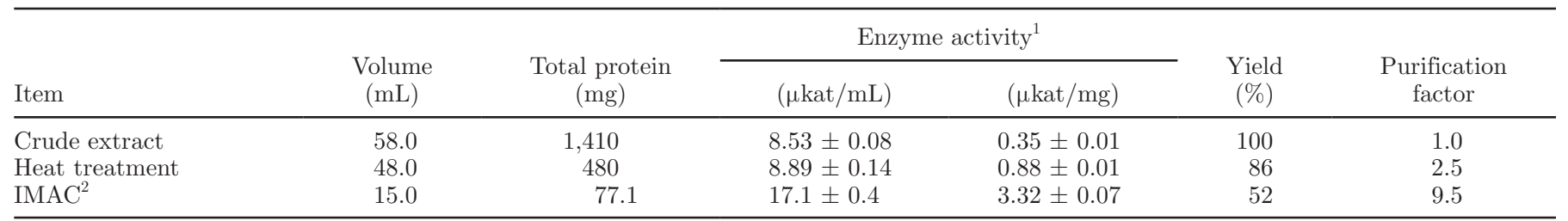

${ }^{1} \mathrm{Cs} \mathrm{CE}$ activity was determined using the standard assay at $80^{\circ} \mathrm{C}$, measuring the epilactose generation.

${ }^{2} \mathrm{IMAC}=$ immobilized metal affinity chromatography.

$61 \%)$, and $0.14 \pm 0.00 \mu$ kat $_{\text {epilactose, }} 8^{\circ} \mathrm{C} / \mathrm{mg}_{\text {protein }}$ at $8^{\circ} \mathrm{C}$ (approximately $4.4 \%$ ).

As the $C s \mathrm{CE}$ is a thermophilic enzyme with a temperature optimum of about $80^{\circ} \mathrm{C}$ ( $\mathrm{Kim}$ and $\mathrm{Oh}, 2012$ ), investigations in milk at $50^{\circ} \mathrm{C}$ were carried out first.

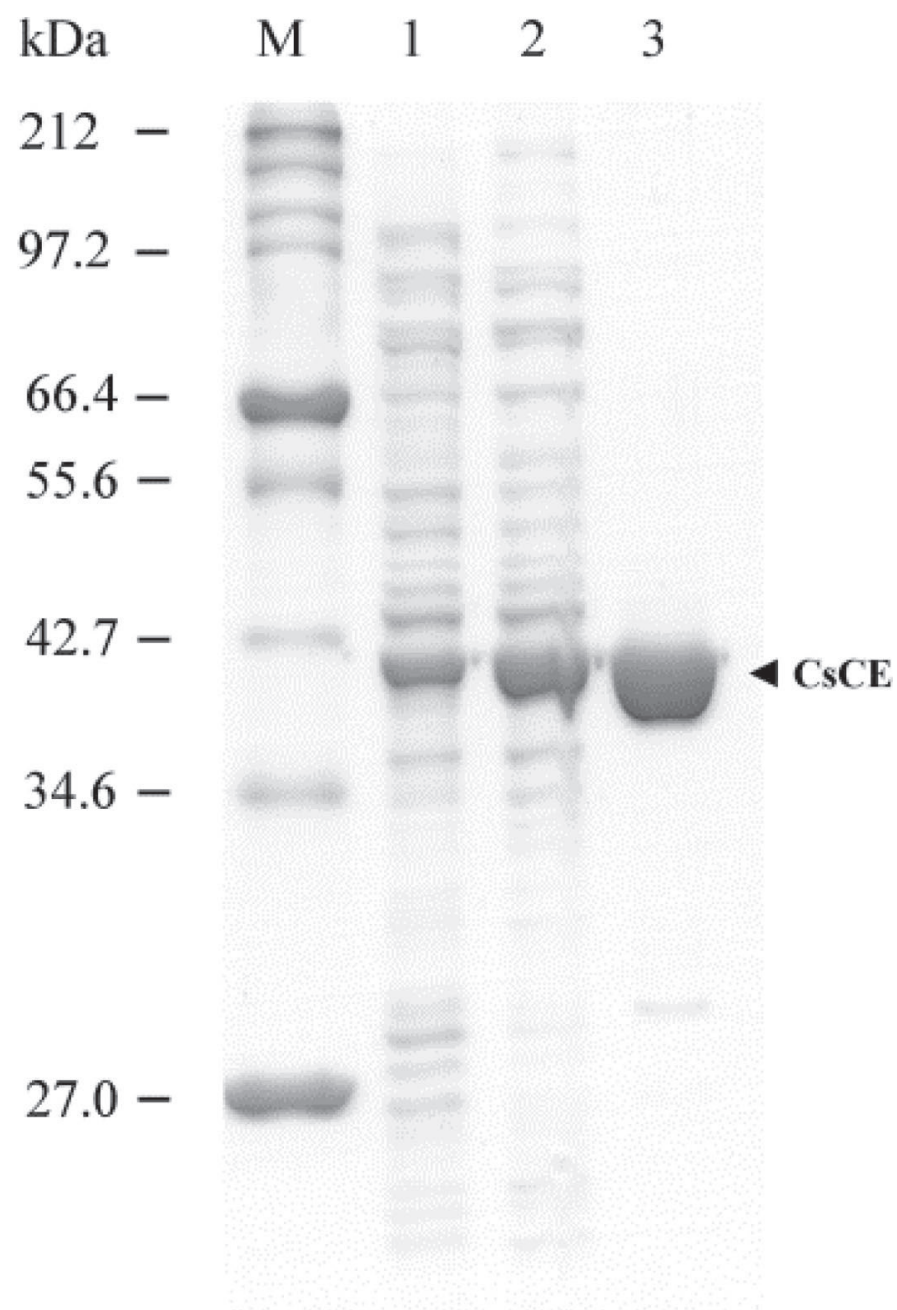

Figure 1. The SDS-PAGE analysis of the purification of recombinant cellobiose 2-epimerase from Caldicellulosiruptor saccharolyticus $(C s \mathrm{CE})$. Lane M: molecular mass marker; lane 1: crude extract after cell disruption; lane 2: heat-treated sample; lane 3: $C s \mathrm{CE}$-active fraction after immobilized metal affinity chromatography (IMAC); $5 \mu \mathrm{g}$ of protein per lane, each.
Here, 2 bioconversions with different initial $C s \mathrm{CE}$ activities of $4.16 \pm 0.21 \mu \mathrm{kat}_{\text {epilactose, } 50^{\circ} \mathrm{C}}$ (Figure $2 \mathrm{~A}$ ) and $39.5 \pm 1.4 \mu \mathrm{kat}_{\text {epilactose, } 50^{\circ} \mathrm{C}}$ (Figure $2 \mathrm{~B}$ ) were performed. Figure 2 shows the first $6 \mathrm{~h}$ of the enzymatic lactose conversions, because the sugar concentrations in both experiments showed almost no change after this time (Supplemental Figure S1; http://dx.doi.org/10.3168/ jds.2015-9900). The first and rapidly formed product of lactose conversion to be produced by the $C s \mathrm{CE}$ in both cases (Figures 2A and 2B) was epilactose. The maximum epilactose concentration was reached after about 5 min (Figure 2B) or 40 min (Figure 2A). After that, the epilactose concentration steadily decreased until the equilibrium of the reaction was reached after about $6 \mathrm{~h}$ (Figure 2B) or it established an almost constant level (Figure 2A). In contrast to the epilactose formation, lactulose apparently appeared with a delay and its concentration increased over the first $6 \mathrm{~h}$. This maximum concentration reached after $6 \mathrm{~h}$ was almost constant until the end of the experiment ( $24 \mathrm{~h}$; Supplemental Figure S1; http://dx.doi.org/10.3168/jds.20159900). These findings lead to the assumption that the CsCE first epimerized lactose to epilactose very rapidly, and second, epilactose was isomerized to lactulose in a slower reaction. Regarding the product yields of the epimerization/isomerization reaction at the 2 different $C s \mathrm{CE}$ activities applied at $50^{\circ} \mathrm{C}$, it was found that the resulting yields depend on the activity added initially ( $C s \mathrm{CE}$ amount).

The lactulose yields (\% wt/wt) related to initial milk lactose $\left(\boldsymbol{Y}_{\text {lactu/lacto }}\right)$ increased from 8.91 to $57.7 \%$, respectively, and in parallel, the epilactose yields (\% wt/ wt) related to initial milk lactose $\left(\boldsymbol{Y}_{\text {epi/lacto }}\right)$ decreased from 33.6 to $15.5 \%$ when using a 9.5 -fold higher initial enzyme activity. The enzyme was active throughout the process time in both cases and showed 9.30 and $7.41 \%$ residual $C s \mathrm{CE}$ activity, respectively.

Another study was performed at $8^{\circ} \mathrm{C}$ to evaluate the lactulose production at a typical temperature for milk processing. For this experiment, an initial $C s \mathrm{CE}$ activ-

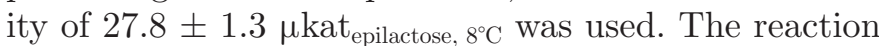
was followed over $72 \mathrm{~h}$ (Figure 3). The principal generation of epilactose and lactulose formation appeared 


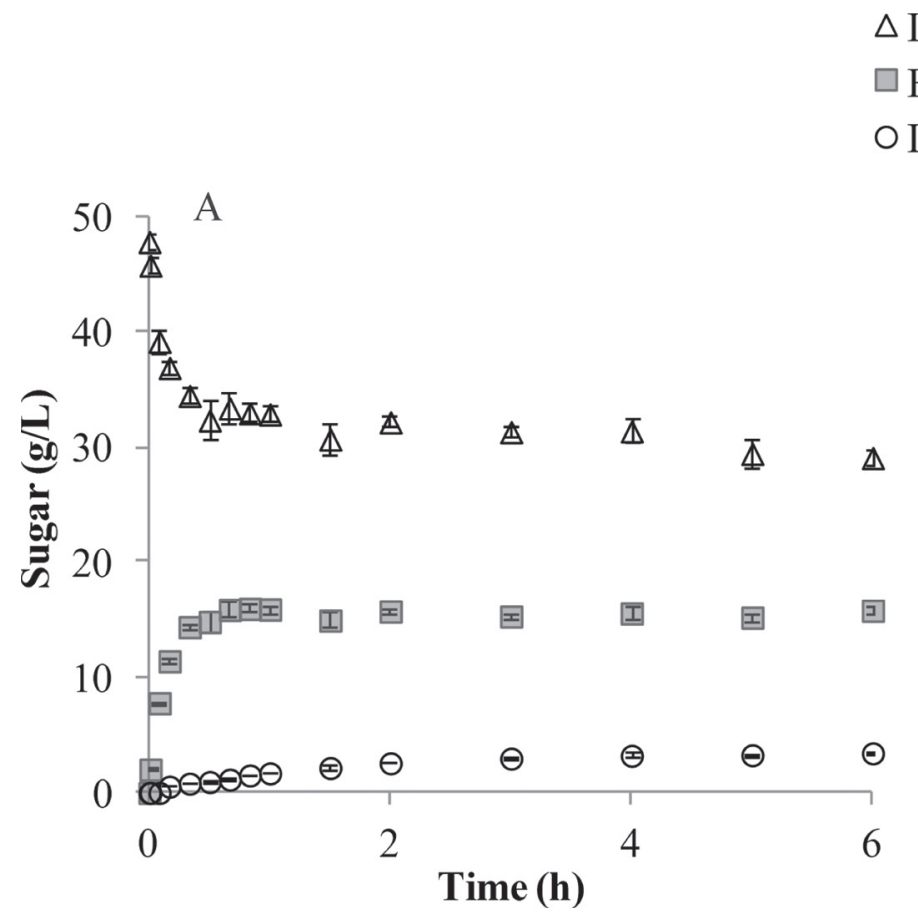

\section{$\triangle$ Lactose \\ $\square$ Epilactose \\ O Lactulose}

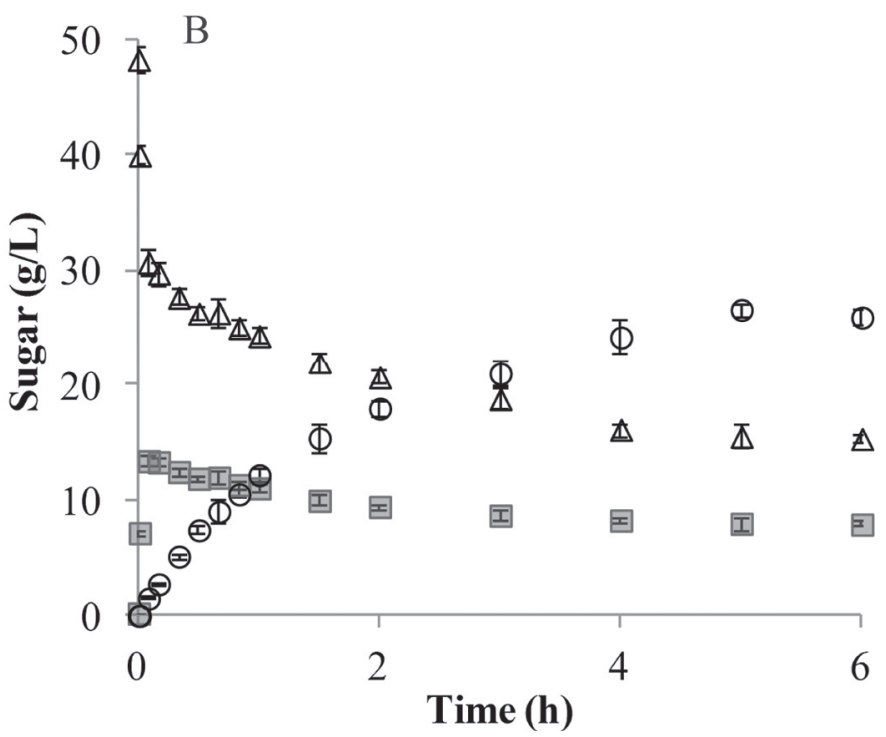

Figure 2. Time course studies of enzymatic lactose conversions by Caldicellulosiruptor saccharolyticus $(C s \mathrm{CE})$ in milk at $50^{\circ} \mathrm{C}$ : $(\mathrm{A})$ addition

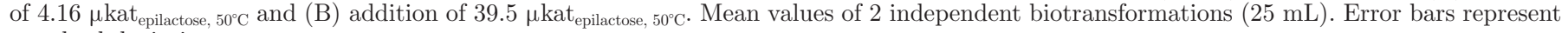
standard deviation.

similar to that at $50^{\circ} \mathrm{C}$, but slower than expected: first, epilactose was generated, and then the epilactose concentration decreased. Second, lactulose was produced permanently over time and the apparent maximum was reached after $72 \mathrm{~h}$.

In conclusion, by addition of an initial $C s \mathrm{CE}$ activity

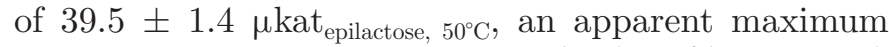
of lactulose production of $28.0 \mathrm{~g} / \mathrm{L}\left(57.7 \% \quad Y_{\text {lactu/lacto }}\right)$ in milk was reached at $50^{\circ} \mathrm{C}$ within $24 \mathrm{~h}$. Additionally, the $C s \mathrm{CE}$ produced $7.49 \mathrm{~g} / \mathrm{L}\left(15.5 \% Y_{\text {epi/lacto }}\right)$ epilactose from the milk lactose $(48.5 \pm 2.1 \mathrm{~g} / \mathrm{L})$. In the case of the lactose conversion at $8^{\circ} \mathrm{C}$, a high residual $C s \mathrm{CE}$ activity of $72 \%$ was determined after $72 \mathrm{~h}$. The maximum epilactose concentration of $13.5 \mathrm{~g} / \mathrm{L}(27.9 \%$ $\left.Y_{\text {epi/lacto }}\right)$ was reached after $40 \mathrm{~min}$. Subsequently, the epilactose concentration decreased to $6.57 \mathrm{~g} / \mathrm{L}(13.6 \%$ $\left.Y_{\text {epi/lacto }}\right)$ after $72 \mathrm{~h}$. Lactulose was produced throughout the whole bioconversion time and the apparent maximum of $27.5 \mathrm{~g} / \mathrm{L}\left(56.7 \% \quad Y_{\text {lactu/lacto }}\right)$ was reached after $72 \mathrm{~h}$. In summary, the enzymatic lactose conversions with $C s \mathrm{CE}$ showed similar results concerning the final product yields at 50 and $8^{\circ} \mathrm{C}$. The final lactulose yields were clearly dependent on the initial amount of $C s \mathrm{CE}$, as can be seen in Figure 2. An investigation concerning the thermal resistance of $C s \mathrm{CE}$ was performed from an industrial point of view. Here, the $C s \mathrm{CE}$ activity of $108 \pm 4.96$ nkat $_{\text {epilactose, }} 50^{\circ} \mathrm{C} / \mathrm{mL}_{\text {milk }}$, corresponding to the residual activity after $24 \mathrm{~h}$ of enzymatic lactose conversion in milk, was subjected to UHT processing conditions $\left(12 \mathrm{~s}\right.$ at $\left.138^{\circ} \mathrm{C}\right)$. No residual activity could be determined after this treatment.

\section{DISCUSSION}

The cultivation and expression of $C s \mathrm{CE}$ with the vector/host system E. coli BL21 (DE3) pET-20bCSCE

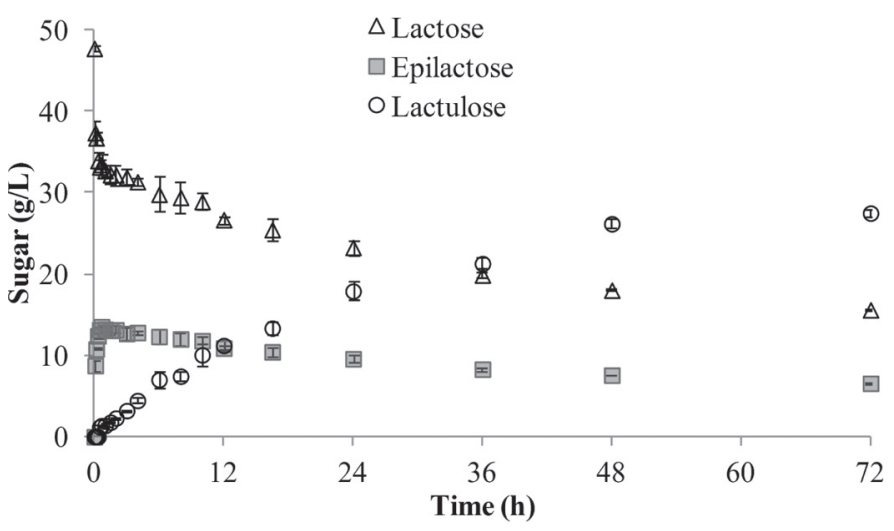

Figure 3. Time course study of lactulose enzymatic lactose conversions by Caldicellulosiruptor saccharolyticus (CsCE) in milk at $8^{\circ} \mathrm{C}$

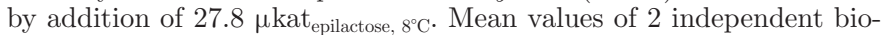
transformations $(25 \mathrm{~mL})$. Error bars represent standard deviation. 
used was performed in 30-times larger scale than described before (Kim and Oh, 2012). The purification of $C s \mathrm{CE}$ with His-Trap affinity chromatography (Table 1) led to similar results as described previously (Kim and Oh, 2012). The enzyme activity produced in our study $\left(3.32 \mu\right.$ kat $\left._{\text {epilactose, }} 80^{\circ} \mathrm{C} / \mathrm{mg}_{\text {protein }}\right)$ with lactose as the substrate was approximately 6.6 times higher than described before (Kim and Oh, 2012; Gu et al., 2015). However, it has to be taken into account that the activity measurements were based on the formation of lactulose, the second product formed, whereas in our study, we defined the $C s \mathrm{CE}$ activity corresponding to epilactose generation, the first and only product formed during the assay period (4 to $10 \mathrm{~min}$ ).

Common CE, which typically catalyze the epimerization reaction of lactose only to epilactose, were reported to convert lactose to epilactose in milk (Watanabe et al., 2008; Krewinkel et al., 2014; Krewinkel et al., 2015). Recently, a novel additional enzymatic reaction by thermophilic CE was discovered (Park et al., 2011; Kim et al., 2012). The CE from C. saccharolyticus and D. turgidum were able to catalyze an epimerization and an isomerization reaction. Thus, both lactulose and epilactose were generated from lactose in synthetic buffer systems. The in situ production of epilactose and lactulose by $C s \mathrm{CE}$ in milk is demonstrated for the first time in this study. The enzymatic lactose conversions were carried out at 50 and $8^{\circ} \mathrm{C}$, which represented suitable parameters for a later utilization during milk processing, and resulted in almost constant substrate and product concentrations after 6 and 48 h, respectively. The thermophilic $C s \mathrm{CE}$ was capable of producing similar conversion yields of $57.7 \% Y_{\text {lactu/lacto }}$ and $15.5 \% Y_{\text {epi/ }}$ lacto at 8 and $50^{\circ} \mathrm{C}$. These yields are approximately the same as described before for $C s \mathrm{CE}$ using $700 \mathrm{~g} / \mathrm{L}$ lactose as a substrate at $80^{\circ} \mathrm{C}$ in synthetic buffer system at $\mathrm{pH}$ 7.5 (Kim and Oh, 2012). Kim and Oh (2012) demonstrated that these yields were almost independent of the substrate concentration. In accordance with the results obtained by Kim and Oh (2012) and Wang et al. (2015), increasing amounts of initial $C s \mathrm{CE}$ activity resulted in increasing lactulose production, until conversion plateaus were reached (Figure 2). As $C s \mathrm{CE}$ remained active throughout all enzymatic lactose conversions, the reactions most probably reached their equilibrium under these conditions. The enzymatic lactose conversions explicitly illustrated in Figures 2 and 3 provide information about the order of epimerization and isomerization reaction for $C s \mathrm{CE}$. The amount of epilactose always increased in a short period of time ( 5 to $40 \mathrm{~min}$ ) and occurred clearly prior to the first formation of lactulose. We postulate that lactulose was formed later and possibly from epilactose during the reaction course. Therefore, we assume that no further lactulose formation is possible if the amount of epilactose decreases to a certain level. Based on this postulation, no $100 \%$ yield of lactulose is possible under these conditions. Figure 4 illustrates a schematic diagram of the hypothesized relation between the $C s \mathrm{CE}$ isomerization and epimerization reaction. However, more kinetic experiments with other substrates (epilactose, lactulose) are necessary to explain the catalytic mechanism of the $C s \mathrm{CE}$ toward lactose conversion. A suggested mechanism based on crystal structures for CE from $R$. albus and Rhodothermus marinus regarding the epimerization reaction involves 3 histidines (Fujiwara et al., 2013, 2014). No crystal structure is available for $C s \mathrm{CE}$ yet.

Until now, no application of $C s \mathrm{CE}$ for the production of lactulose in milk has been illustrated. The achieved yields are approximately 15\% higher than the highest reported yield ( $Y_{\text {lactu/lacto }} 44 \%$ ) for a transgalactosylation of fructose (Mayer et al., 2004) and are in a comparable range as the yields achieved in chemical isomerization processes ( $Y_{\text {lactu/lacto }} 20$ to $87 \%$ ), but in the case of $C s \mathrm{CE}$ reaction, without any need of a cosubstrate or chemical catalysts (Schuster-Wolff-Bühring et al., 2010; Panesar and Kumari, 2011). In our illustrated process, a maximum of $28.0 \mathrm{~g}$ of lactulose was produced by $C s \mathrm{CE}$ per liter of milk. Considering the fact that prebiotic lactulose-containing products should provide doses of 2 to $10 \mathrm{~g}$ of lactulose/d, the produced milk product may be directly used as a prebiotic drink (Terada et al., 1992; Mizota et al., 2002; Tuohy et al., 2002; Seki et al., 2007). An approximately 72- to $360-\mathrm{mL}$ daily serving portion of a milk serum drink generated by $C s \mathrm{CE}$ would be sufficient for a prebiotic product formulation. This lactulose containing dairy products could be a new approach to extend the range of functional foods and even may lead to a novel way of enhancing the value of by-products as whey. At the end of the process, the inactivation of $C s \mathrm{CE}$ by UHT treatment is possible, indicating a possible later integration of the enzymatic synthesis in processing of a lactulose-enriched dairy product. Hence, the application of $C s \mathrm{CE}$ to produce lactulose and epilactose in milk is a promising approach to enhance the value of milk products in the future.

\section{ACKNOWLEDGMENTS}

Many thanks go to Susanne Herr (Institute of Food Science and Biotechnology) for her help regarding the gene cloning. Also many thanks go to Deborah Böhringer and Jörg Hinrichs (Institute of Food Science and Biotechnology) for their good collaboration. 


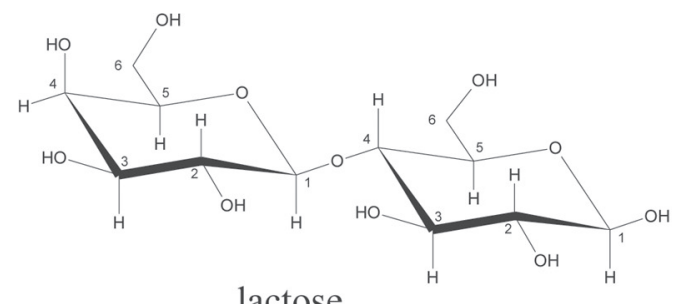

lactose

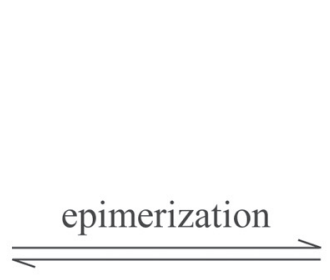

(4- $O$ - $\beta$-D-galactopyranosyl-D-glucopyranose)
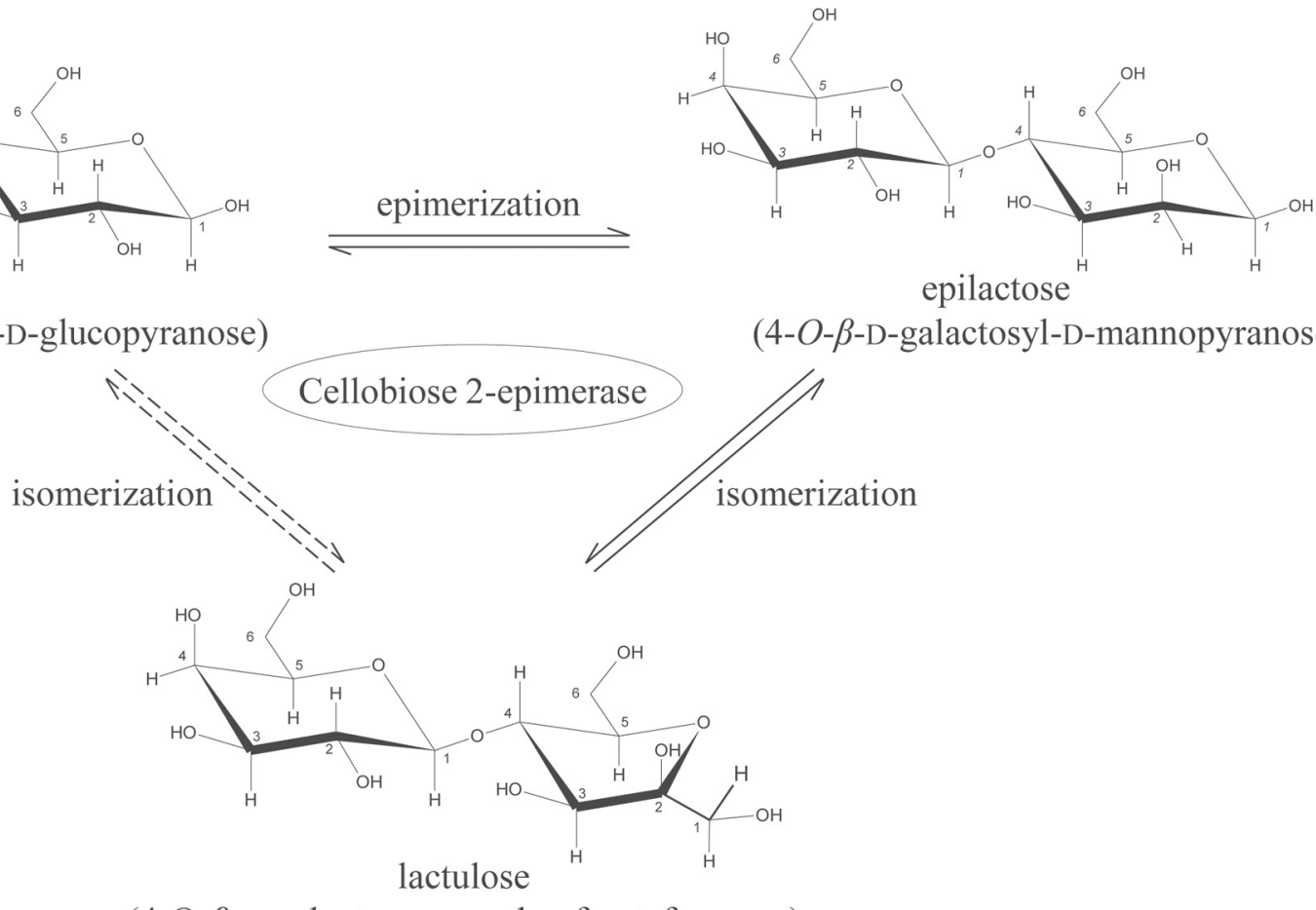

(4-O- $\beta$-D-galactosyl-D-mannopyranose)

(4-O- $\beta$-D-galactopyranosyl-D-fructofuranose)

Figure 4. Schematic diagram of the assumed Caldicellulosiruptor saccharolyticus (CsCE) isomerization/epimerization reaction.

\section{REFERENCES}

Aïder, M., and D. de Halleux. 2007. Isomerization of lactose and lactulose production . Trends Food Sci. Technol. 18:356-364. (Review).

Ait-Aissa, A., and M. Aïder. 2014. Lactulose: Production and use in functional food, medical and pharmaceutical applications. Practical and critical review. Int. J. Food Sci. Technol. 49:1245-1253.

Bradford, M. M. 1976. A rapid and sensitive method for the quantitation of microgram quantities of protein utilizing the principle of protein-dye binding. Anal. Biochem. 72:248-254.

Cattaneo, S., F. Masotti, and L. Pellegrino. 2008. Effects of overprocessing on heat damage of UHT milk. Eur. Food Res. Technol. 226:1099-1106.

Dogan, Z., K. Weidendorfer, M. Müller-Merbach, F. Lembke, and J. Hinrichs. 2009. Inactivation kinetics of bacillus spores in batch-and continuous-heating systems. LWT-Food Sci. Technol. 42:81-86.

Erich, S., T. Anzmann, and L. Fischer. 2012. Quantification of lactose using ion-pair RP-HPLC during enzymatic lactose hydrolysis of skim milk. Food Chem. 135:2393-2396.

Fairbanks, G., T. L. Steck, and D. Wallach. 1971. Electrophoretic analysis of the major polypeptides of the human erythrocyte membrane. Biochemistry 10:2606-2617.

Förster-Fromme, K., R. Schuster-Wolff-Bühring, A. Hartwig, A. Holder, A. Schwiertz, S. C. Bischoff, and J. Hinrichs. 2011. A new enzymatically produced 1-lactulose: A pilot study to test the bifidogenic effects. Int. Dairy J. 21:940-948.

Fujiwara, T., W. Saburi, S. Inoue, H. Mori, H. Matsui, I. Tanaka, and M. Yao. 2013. Crystal structure of Ruminococcus albus cellobiose 2-epimerase: Structural insights into epimerization of unmodified sugar. FEBS Lett. 587:840-846.

Fujiwara, T., W. Saburi, H. Matsui, H. Mori, and M. Yao. 2014. Structural insights into the epimerization of $\beta$-1,4-linked oligosaccharides catalyzed by cellobiose 2 -epimerase, the sole enzyme epimerizing non-anomeric hydroxyl groups of unmodified sugars. J. Biol. Chem. 289:3405-3415.
Gaucher, I., D. Mollé, V. Gagnaire, and F. Gaucheron. 2008. Effects of storage temperature on physico-chemical characteristics of semiskimmed UHT milk. Food Hydrocoll. 22:130-143.

Gu, J., R. Yang, X. Hua, W. Zhang, and W. Zhao. 2015. Adsorptionbased immobilization of Caldicellulosiruptor saccharolyticus cellobiose 2-epimerase on Bacillus subtilis spores. Biotechnol. Appl. Biochem. 62:237-244

Guerrero, C., C. Vera, F. Plou, and A. Illanes. 2011. Influence of reaction conditions on the selectivity of the synthesis of lactulose with microbial $\beta$-galactosidases. J. Mol. Catal., B Enzym. 72:206-212.

Ito, S., H. Taguchi, S. Hamada, S. Kawauchi, H. Ito, T. Senoura, J. Watanabe, M. Nishimukai, S. Ito, and H. Matsui. 2008. Enzymatic properties of cellobiose 2-epimerase from Ruminococcus albus and the synthesis of rare oligosaccharides by the enzyme. Appl. Microbiol. Biotechnol. 79:433-441.

Kim, J.-E., Y.-S. Kim, L.-W. Kang, and D.-K. Oh. 2012. Characterization of a recombinant cellobiose 2-epimerase from Dictyoglomus turgidum that epimerizes and isomerizes $\beta$-1,4- and $\alpha$-1,4-glucooligosaccharides. Biotechnol. Lett. 34:2061-2068.

Kim, Y.-S., and D.-K. Oh. 2012. Lactulose production from lactose as a single substrate by a thermostable cellobiose 2-epimerase from Caldicellulosiruptor saccharolyticus. Bioresour. Technol. 104:668672.

Kim, Y.-S., C.-S. Park, and D.-K. Oh. 2006. Lactulose production from lactose and fructose by a thermostable $\beta$-galactosidase from Sulfolobus solfataricus. Enzyme Microb. Technol. 39:903-908.

Krewinkel, M., M. Gosch, E. Rentschler, and L. Fischer. 2014. Epilactose production by 2 cellobiose 2-epimerases in natural milk. J. Dairy Sci. 97:155-161.

Krewinkel, M., J. Kaiser, M. Merz, E. Rentschler, B. Kuschel, J. Hinrichs, and L. Fischer. 2015. Novel cellobiose 2-epimerases for the production of epilactose from milk ultrafiltrate containing lactose. J. Dairy Sci. 98:3665-3678.

Laemmli, U. K. 1970. Cleavage of structural proteins during the assembly of the head of bacteriophage T4. Nature 227:680-685. 
Manzi, P., and L. Pizzoferrato. 2013. HPLC determination of lactulose in heat treated milk. Food Bioprocess Technol. 6:851-857.

Mayer, J., J. Conrad, I. Klaiber, S. Lutz-Wahl, U. Beifuss, and L. Fischer. 2004. Enzymatic production and complete nuclear magnetic resonance assignment of the sugar lactulose. J. Agric. Food Chem. 52:6983-6990.

Mayer, J., B. Kranz, and L. Fischer. 2010. Continuous production of lactulose by immobilized thermostable $\beta$-glycosidase from Pyrococcus furiosus. J. Biotechnol. 145:387-393.

Mizota, T., T. Mori, T. Yaeshima, T. Yanagida, K. Iwatsuki, N. Ishibashi, Y. Tamura, and Y. Fukuwatari. 2002. Effects of low dosages of lactulose on the intestinal function of healthy adults. Milchwissenschaft 57:312-315.

Oku, T., and M. Okazaki. 1998. Transitory laxative threshold of trehalose and lactulose in healthy women. J. Nutr. Sci. Vitaminol. (Tokyo) 44:787-798.

Olano, A., and N. Corzo. 2009. Lactulose as a food ingredient. J. Sci. Food Agric. 89:1987-1990.

Panesar, P. S., and S. Kumari. 2011. Lactulose: Production, purification and potential applications. Biotechnol. Adv. 29:940-948.

Park, C.-S., J.-E. Kim, J.-G. Choi, and D.-K. Oh. 2011. Characterization of a recombinant cellobiose 2-epimerase from Caldicellulosiruptor saccharolyticus and its application in the production of mannose from glucose. Appl. Microbiol. Biotechnol. 92:11871196.

Petuely, F. 1957. Bifidusflora bei Flaschenkindern durch bifidogene Substanzen (bifidusfaktor). Z. Kinderheilkd. 79:174-179.

Richards, M., H. L. De Kock, and E. M. Buys. 2014. Multivariate accelerated shelf-life test of low fat UHT milk. Int. Dairy J. 36:3845.

Sambrook, J., and D. W. Russell. 2001. Molecular Cloning: A Laboratory Manual. Cold Spring Harbour Laboratory Press, New York, NY.
Schuster-Wolff-Bühring, R., L. Fischer, and J. Hinrichs. 2010. Production and physiological action of the disaccharide lactulose. Int. Dairy J. 20:731-741.

Seki, N., H. Hamano, Y. Iiyama, Y. Asano, S. Kokubo, K. Yamauchi, Y. Tamura, K. Uenishi, and H. Kudou. 2007. Effect of lactulose on calcium and magnesium absorption: A study using stable isotopes in adult men. J. Nutr. Sci. Vitaminol. (Tokyo) 53:5-12.

Seki, N., and H. Saito. 2012. Lactose as a source for lactulose and other functional lactose derivatives. Int. Dairy J. 22:110-115.

Sharma, P., B. C. Sharma, V. Puri, and S. K. Sarin. 2008. An openlabel randomized controlled trial of lactulose and probiotics in the treatment of minimal hepatic encephalopathy. Eur. J. Gastroenterol. Hepatol. 20:506-511.

Terada, A., H. Hara, M. Kataoka, and T. Mitsuoka. 1992. Effect of lactulose on the composition and metabolic activity of the human faecal flora. Microb. Ecol. Health Dis. 5:43-50.

Tossavainen, O. 2008. Heat-induced changes in lactose hydrolysed milks. Doctoral Thesis, Helsinki University of Technology, Espoo, Finland.

Tuohy, K. M., C. J. Ziemer, A. Klinder, Y. Knöbel, B. L. Pool-Zobel, and G. R. Gibson. 2002. A human volunteer study to determine the prebiotic effects of lactulose powder on human colonic microbiota. Microb. Ecol. Health Dis. 14:165-173.

Wang, M., R. Yang, X. Hua, Q. Shen, W. Zhang, and W. Zhao. 2015. Lactulose production from lactose by recombinant cellobiose 2-epimerase in permeabilised Escherichia coli cells. Int. J. Food Sci. Tech. 50:1625-1631. http://dx.doi.org/10.1111/ijfs.12776.

Watanabe, J., M. Nishimukai, H. Taguchi, T. Senoura, S. Hamada, H. Matsui, T. Yamamoto, J. Wasaki, H. Hara, and S. Ito. 2008. Prebiotic properties of epilactose. J. Dairy Sci. 91:4518-4526. 